\title{
Consumer policy in Poland's process of accession to the European Union
}

\section{Introductory remarks}

The Polish accession process to the European Union was connected with unification of Polish and European consumer policies. Consumer policy, in this particular context, was defined as the total of conscious efforts that aim to create conditions to allow consumers to achieve their goals in terms of disposal of their incomes and the fulfilment of their needs (Niepokulczycka, 1998, p. 105). The primary purpose of this article is to analyse the way, scope and the essence of adaption of consumer policy in the process of Poland's accession to the European Union. The main focus is on the aspect of adjusting consumer legislation to the European standards.

It has been indicated that the major tool used for adapting Polish consumer policy to the European standards was the adjustment of the norms that guaranteed consumer protection in the EU and common respect for the standards in communications, resolutions, recommendations and opinions. The actions may be divided into; regulatory - legal structure referring to the unification of Polish and European consumer legislation, and socio-organizational structure focused on creating institutional background and on working on pro-consumer standards in the area of consumer claims or during the process of purchase.

Consumer policy is one of the elements of socio-economic policy followed by the member countries. It guarantees high standards of health care, security of economic interests and support for consumer rights for information, education and representation. European consumer policy aims to coordinate consumer interests, stimulate positive consumer activities and protect them against professional manufacturers and the goods and services suppliers (Banasiński, 2004, p. 15).

Protection of consumer rights in the European Union covers a wide range of activities within a number of spheres (Rokicka, 1998, p. 35). It consists of a few elements: legislations regulated by the Community Treaties and acts issued by selected EU institutions. The second group includes: legislative acts (regulations and directives) and acts with no legal binding force (resolutions, reccommendations and communications). The creation and implementation of policy is possible through the activity of EU institutions, and consumer organizations promoting consumer interests. The standards and the concept of measures within the area of consumer protection are successively realised in accordance with strategies and programmes of consumer policy. The documents that cover a number of years, indicate the need for implementing appropriate organizational and legal solutions. 
They include short and long-term objectives that need to be met by a particular deadline. As a general rule, national consumer policy and legal regulations shall be consistent with the European standards. It supports consumer protection during the process of purchase and redress when the goods are incompatible with EU requirements.

\section{Legal standards in regard to consumer protection in the European Union}

The scope of consumer protection in the European Union is regulated by foundation Treaties and the secondary law instruments - directives (Dynia, 2004, p. 132). The forms of Community consumer policy do not have their own specifics that may distinguish them from the other forms of EU legislation. In that case, the features of EU legislation refer to the consumer policy (Legislation). The Treaty of Maastricht that established the European Union (The Treaty of European Union) added point XI "consumer protection" to the list of policies. According to Article 129 paragraph 1 of the Treaty, the Union was obliged to act in favour of consumer protection. The actions of the Union were supposed to standardise the regulations referring to health protection, security of consumers and their interests, and provide them with relevant information (Doliwa-Klepacki, 2000, p. 12). The Treaty of Amsterdam from $2^{\text {nd }}$ October 1997 (The Treaty of Amsterdam) formed the legal basis and new frames of activities for the Community. As a result, Article 129a of the Treaty that established the European Community increased the scope of consumer protection. At Community level it included: health protection, protection of consumers and their economic interests, the right to information, education and self-organisation. The Community used certain instruments that support and supervise the policies of Member States in order to fulfil the abovementioned objectives (Art. 153 bill 3). On the basis of Art. 153, paragraph 1 (The Treaty on European Union) we can discuss the interests and rights of consumers. The interests regarding protection included: health protection, security and economic interests, whereas the laws included: the right to information, education and self-organisation (Maliszewska-Nienartowicz, 2004, p. 194).

Among the most important acts of European legislation regarding consumer protection we may distinguish the directive about economic interests and security and safety of consumer's health. They were included in the legislation of selected Member States. It resulted in the harmonisation of consumer policies, created the legal basis for protection of consumer interests in the Union and active consumer policy-making (Streżyńska, 2000, p. 12).

Since 1993 the economic model of the European Union acting as a guarantor within the area of consumer protection has been beyond question, however the real influence of the changes described by the Treaty has not been comprehensive. The Treaty specified the measures that served customer protection in a very general manner. They only set the direction of actions leaving the rest to the directives and soft law political declarations (Włodarska-Dziurzyńska, 2009, p. 47; Weatherill, 2005, p. 4). 


\section{The stages of adjusting Polish consumer policy}

We can distinguish three time phases connected with the adjustment process within the field of consumer policy. The first stage from 1989 was the breakthrough for the transformation of the Polish system, and was connected with the changes in every possible area: mobilising the market mechanism; accepting a federal programme of economic stabilisation; introducing internal exchange of the Złoty; structural transformations. The second stage began in 1991 with the signing of the the Europe Agreement which established association between Poland, the European Community and its Member States. This stage was connected with institutional reforms and with adjusting consumer legislation to European standards. The third stage started after Poland's accession to the Union on $1^{\text {st }}$ May 2004 (Małysa-Kaleta, 1999, p. 268-269).

Analysing consumer policy in Poland until 1989, it is necessary to highlight the fact that it was mainly concerned about protection against criminal behaviour within the field of trade of goods (Kołodziejek, 1975, p. 56, 59). The People's Republic of Poland did not carry out a complex consumer policy. Some signs of dangers to consumer rights were treated as a result of inconsistency in the capitalist economy, and its socializations and planning as a guarantee for the implementation of socio-economic politicies (Łętowska, 1983, p. 400). The development of pro-consumer politics was hindered by the lack of basic goods on the market and the low quality of production (Żuławska, 1994-1995, pp. 379-380).

Transformation to the federal system in 1989 resulted in a number of changes that aimed to create an effective and modern market economy. Political changes led to radical changes in the economy. The most important change was the introduction of free market regulation, which entailed leaving the central model of controlling the economy and opening borders to new goods and their wide variety, and finally the rule of competition. However, the lack of legal regulations and unsupervised activity of traders caused potential danger to consumers (Ozimek, 1999, p. 282). In Poland, the belief held that in spite of the fact that a socialized economy was meant to fulfil the social needs and interest and not to raise possible dangers, it was an inherent consequence of the political system. The change of system fuelled the belief that the free market and competition solve the problem of consumer protection (Łętkowska, 1994, p. 3 ).

The second stage in integration the consumer policy with EU standards is dated from $16^{\text {th }}$ December 1991 when the Europe Agreement between Poland and the European Communities was signed (Układ Europejski, 1991).

According to the Agreement integration is identified with harmonization defined as adjusting one legal system to the standards of another. The European Union was obliged to support the process technically, intellectually and financially, however the main activity was to be performed by Poland. Under Article 70 of the Act, in order to fulfil the objectives, the EC provided technical support that included: the exchange of experts, providing information, holding seminars, training sessions and help in translation of the legislation regarding customer protection. Under Article 58 of the Agreement, the introductory condition for economic integration with the Union was a process of gradual alignment of existing and future Polish legislation to the European legislation. Poland was obliged to make every possible effort to harmonise their 
legislation with the European equivalent (Brodecki, Gromnicka, 2002, pp. 99-100). In order to reach full economic integration, Poland had to harmonise their legislation and separate the economic processes from the governmental decisions which affected macro and micro-economic processes. According to Article 69 of the Act, adaptation of the regulations included: the rules of competition, protection of health and life with the broadly understood scope of protection of consumers. Article 69 formulated priorities in the harmonisation process, they could be separated into two groups. The first group referred to the norms regulating the legal situation and functioning of the enterprise, and the norms regulating commercial transactions, whereas second group included consumer protection, regulations of customs and excise, technical standards, finances, taxes and internal and external monetary transactions. The process of adjustment changed when Poland entered the second stage of accession and when it started negotiations to join the Union. In consequence, the Polish government, on $23^{\text {rd }}$ June 1998 accepted the National Programme for adoption. The programme set the direction of the adoption activities and specified a time between 1998-2002 for their implementation. The major requirement was to prepare a law regulating safety of goods, a law regarding the agreements made away from business premises and a law about change in the Civil Code, the Code of Civil Procedure and the Statue of Frauds regarding illegal clauses and their control, responsibility for the unsafe products and the law about purchasing the laws for the usage of buildings or residential buildings. Systematically, Poland was supposed to prepare the laws concerning toy safety, consumer credits and other legal acts aiming to adjust national regulations to those of the EU. There was a plan of establishing an institution for market checks.

A further step in the process of integration was an agreement between the President of the Polish Parliament, the Senate speaker and the President of the Council of Ministers on $10^{\text {th }}$ July 2000 . Under the Act of Polish Parliament, an extraordinary committee for European Legislation was established on $13^{\text {th }}$ July 2000. It consisted of three MPs who represented all political parties. The Committee dealt with the legislation drafts for adjusting Polish law to European one. The established Acts could be divided into two categories: collective acts adjusting regulations concerning a few areas of law, and the so-called integrated acts adjusting regulations concerning specific areas of law. From $1^{\text {st }}$ August 2000 the Department for EU Legislation in the office of the Committee for European Integration became responsible for the coordination and fulfilment of requirements regarding the adjustment of consumer policy (Information).

In accordance with the approach to negotiations over accession, Poland shared the priority requirements and the objectives of the European policy in the field of "Consumer and health protection." Poland accepted the implementation of acquis communautaire in the area of consumer policy. Implementation activities included harmonisation of the law and strengthening administrative structures of the market control. In accordance with the declaration, Poland implemented selected EU legal Acts into the Polish legislation by the year 2000, with the exception of directive 87/102/EWG about consumer credit, which was to be fully implemented by 2002. The other adjustment processes were finished on the date set by the Polish Council of Ministers and defined as a date for willingness for accession. It has been indicated that the Union acts regarding consumer rights that needed to be implemented either did not have any equivalent 
in Polish law or were not yet introduced. The directives concerning the so-called "new approach," and the security of selected products present in the market, were not included in the implementation list.

The third stage of integration started after 2004. Polish accession to the European Union (Traktat, 2003) allowed for an increase in the protection of Polish consumers and consumer-policy making using the measures of the Community, especially Community's consumer institutions. Poland began work on the objectives of EU consumer policy in May 2004. It started to work on establishing structures that would aim to provide consumers with the best possible assistance in redress process in the European market. These institutions included: European Centre for Consumer Information working as OCCP since January 2005 as an EEJ-net system (European Extra-Judical Network). Apart from consumer policy-making, "the Centre" provided legal and organisational assistance in case of cross-border disputes, including out-of-court settlement of consumer disputes. Since $1^{\text {st }}$ May 2004, Poland has taken part in all forms of institutional work that guarantees product safety. Among others, the activities include the system of fast information flow about the dangerous products for the States of EU. The main task of the system was to provide fast exchange of information between the Member States and the European Commission regarding hazardous products, in order to exclude them from usage and from the market. The system is systematically updated with information about the dangerous products and the remedial measures taken by the traders. Within the frames of the system, the Commission informed Poland and other Member States about the products which were confirmed to be hazardous in other countries of EU (Polska).

After Poland's accession to the EU, the overriding EU objectives regarding consumer policy coincide with the national priorities. It is covered by the idea of unified and safe cross-border market, barrier-free for the average consumer. The current, national, consumer policy for the years 2014-2018 (Polityka, 2014, pp. 30-61) is same as consumer policy of European Union for years 2014-2018 (Parlament Europejski, 2014). Both documents aim to provide consumers with a high level of protection and to strengthen the consumer's position by placing the purchaser at the centre of the internal market within the frames of strategies for intelligent and sustainable economic growth. Increasing consumer protection in terms of a regular market supervision, information, education and support for consumer, institutions should contribute to assure product safety. In terms of policies, there is a need for development and strengthening consumer rights through intelligent regulatory actions and improvement in access to a simple, effective and cheap redress system, including alternative methods of dispute resolution. An important matter at both the national and EU level is the support for executing consumer law by means of strengthening the cooperation between the national and international institutions responsible for overseeing consumer's disputes.

\section{Conclusions}

After 1989 in Poland, consumer policy was defined as a subsidiary product of competitive policies. After some period of time, it turned out that protection of competition 
will not profile consumer protection, which led to a gradual separation of consumer law as an independent policy of the Community (Łętowska, 2002, p. 15). Along with the development of the idea of Polish and EU integration consumer issues have started to be resolved in terms of legislative policy that was dependent on European Communities and not determined by individual aspirations or customer's claims (Strużycki, 2005, p. 253).

The position of the consumer in European Union was highly dependent on economic situation and economic growth that lead to increased production and consumption. There are two stages distinguished in the development process of policy concerning consumer protection in the Union. Until 1992, legislation concerning customer protection was a derivative of the regulations that created the basis for free competition The comfort and living standards of the consumers as a result of the main objective, were going to be of secondary importance (Dąbrowska, Janoś-Krzesło, Ozimek, 2007, p. 34). After signing the Maastricht Treaty, the consumer became the main object of integration which was aimed to improve consumer state of being, who was formerly treated as the recipient of the supply of goods and services appearing on the integrated, competitive, and non-discriminatory market (Niepokulczycka, 1998, p. 25). The role of the consumer in the European Union changed from the passive market participant, whose protection was a necessary effect and the sum of activities addressed to the active market participants, into an independent partner who has the possibility to influence policy-making concerning his situation.

At first, the integration of Polish and EU policies was supposed to work in favour of the flow of goods, services, workforce, possibility of establishing branches, competitiveness and the lack of discrimination within the economic activity. The matters of consumer protection were treated in terms of declarations, while the burden of practical activities fell on the consumer organizations. The creation of an integrated market and implementation of EU legislation gave the consumers new possibilities: greater access to goods and services and better protection and assertion of laws.

Despite the full integration of national and European policy, we can observe consumers who are rather poorly educated about their rights. That problem is especially observed in those EU countries where the transformation of system allowing for effective and modern market was a rather fresh issue. Consequently, it was vital to carry out supranational consumer policy that aimed to provide clear information, strengthen the position of the consumer in the relationships with the goods and services, manufacturers and suppliers, protection of health and economic interests, ensuring effective procedures of executing consumer allowances and to create possibility for respecting opinions and views concerning consumers.

It is important to notice that there were discrepancies in the EU legal system, especially regarding divergence in consumer questions in different legal acts. The parallel use of the directive about agreements made outside business premises and the directive about timesharing may serve as an example. Furthermore, the right of withdrawal and the way it is described in the directives about agreements made outside business premises, distance contracts, timesharing and distance sales are different regarding the length of the way the period of notice is calculated. Is some cases the application is differently regulated. The other group of issues concerning the same category is 
connected with the different understandings of the concepts like: agreement or damage. These concepts usually lack a common definition. It gives the national legislators freedom in the process of integration. That led to a situation whereby the national laws are unified with the European ones only in theory and not in practice. In other cases, the concepts are defined within one group of directives. ${ }^{1}$ The point of difference is still a question "If there exists a definition in any of the directives, it should be binding in interpretation of other directives." Within that approach there is a risk of dispersion of national legislation. ${ }^{2}$ A further problem is the presence of two distinctive legislation methods, which may result in discrepancies in the application of the same directive. Such a situation may be observed in the case of directive about e-commerce, where we can find differences between the law of ownership for the a contract and the applicable law for the marketing activities (Wiewiórska-Domagalska, 2000, p. 45).

\section{Bibliography}

Banasiński C. (2004), Prawo ochrony konsumenta, in: Standardy wspólnotowe w polskim prawie ochrony konsumenta, ed. C. Banasiński, Warszawa.

Brodecki Z., Gromnicka E. (2002), Układ Europejski z komentarzem, Warszawa.

Dąbrowska A., Janoś-Kresło M., Ozimek I. (2007), Konsumpcja w krajach Europy ŚrodkowoWschodniej, Warszawa.

Doliwa-Klepacki Z. M. (2000), Integracja europejska, Białystok.

Dynia E. (2004), Integracja europejska, Warszawa.

Informacja Rzadu RP dla Sejmu RP o przebiegu negocjacji o członkowstwo w Unii Europejskiej. Obszar ochrona konsumentów i zdrowia, „Biuletyn Urzędu Ochrony Konkurencji i Konsumentów," no. 26.

Kołodziejek B. (1975), Interpretacja zjawiska naruszania interesów konsumenta w warunkach gospodarki planowej, in: Interesy konsumentów a działalność handlu. Materiały z konferencji Warszawa-Jadwisin 29-30 X 1973, Warszawa.

Łętowska E. (1983), Kształtowanie się odrębności obrotu mieszanego, in: Tendencje rozwoju prawa cywilnego, ed. E. Łętowska, Wrocław.

Łętowska E. (1994), Ochrona konsumenta negatywny spór kompetencyjny, „Państwo i Prawo,” no. 6.

Łętowska E. (2002), Prawo umów konsumenckich, Warszawa.

Małysa-Kaleta A. (1999), Nowe uwarunkowania zachowań konsumenckich w aspekcie czasowym i przestrzennym (na tle procesów integracyjnych), in: V Międzynarodowa Konferencja Sieci Krajów Grupy Wyszehradzkiej: Konsument i przedsiębiorstwo w przestrzeni europejskiej - etnocentryzm czy globalizacja, eds. K. Karcz, Z. Kędzior, B. Kolny, B. Kucharska, G. Maciejewski, M. Malinowska, B. Mikołajczyk, Katowice.

Narodowy Program Przygotowania do Członkostwa w UE. Synteza dokumentu przyjętego przez rząd 23 czerwca 1998 r. (1998), „Przegląd Rządowy,” no. 9, http://www.kprm.gov.pl/archiwum/7810_7837.htm, 30.03.2012.

Maliszewska-Nienartowicz J. (2004), Ewolucja ochrony konsumenta w europejskim prawie wspólnotowym, Torun.

1 The damage was defined in the directive about the responsibility about the product, however there is no definition in the directive about travel services, it has definition in the directive about distant sales but not in the directive about distant sales of financial services.

${ }^{2}$ Member State has a general definition of a particular legal institution that is adjusted to a specific understanding of the institution used in particular directive. 
Niepokulczycka M. (1998), Polityka konsumencka w Polsce - aspekt integracyjny, in: Socjoekonomiczna i prawna sytuacja konsumentów w Polsce w obliczu integracji z Uniq Europejska, eds. K. Gutkowska, I. Ozimek, Warszawa.

Ozimek I. (1999), Stan świadomości polskich konsumentów w zakresie ochrony konsumenta w Polsce w perspektywie integracji z UE, in: Konsument i przedsiębiorstwo w przestrzeni europejskiej - etnocentryzm czy globalizacja, ed. K. Karcz, Katowice.

Parlament Europejski (2014), Rozporzadzenie Parlamentu Europejskiego Rady UE nr 254/2014 $z$ dnia 26 lutego 2014 r. $w$ sprawie wieloletniego programu na rzecz konsumentów na lata 2014-2020 oraz uchylające decyzję nr 1926/2006/WE, D Urz. UE L 84/42, 20.3.2014.

Polityka konsumencka na lata 2014-2018 (2014), Warszawa.

Polska w Unii Europejskiej doświadczenia pierwszego roku członkostwa (2005), Warszawa.

Rokicka G. (1998), Ustawodawstwo konsumenckie Unii Europejskiej (wybrane aspekty), in: Socjoekonomiczna i prawna sytuacja konsumentów w Polsce w obliczu integracji z Unia Europejska, eds. K. Gutkowska, I. Ozimek, Warszawa.

Streżyńska A. (2000), Ochrona konsumentów w Unii Europejskiej i Polsce, Warszawa.

Strużycki M. (2005), Ochrona konkurencji i konsumentów - konteksty ekonomiczne, in: Ochrona konkurencji i konsumentów w Polsce i Unii Europejskiej (studia prawno-ekonomiczne), ed. C. Banasiński, Warszawa.

Traktat akcesyjny między Królestwem Belgii, Królestwem Danii, Republika Federalna Niemiec, Republika Grecka, Królestwem Hiszpanii, Republika Francuska, Irlandia, Republika Włoska, Wielkim Księstwem Luksemburga, Królestwem Niderlandów, Republika Austrii, Republika Portugalska, Republika Finlandii, Królestwem Szwecji, Zjednoczonym Królestwem Wielkiej Brytanii i Irlandii Pótnocnej (Państwami Członkowskimi Unii Europejskiej) a Republika Czeska, Republika Estońska, Republika Cypryjska, Republika Lotewska, Republikq Litewska, Republika Wegierska, Republika Malty, Rzeczpospolita Polska, Republika Stowenii, Republikg Stowacka dotycząy przystapienia Republiki Czeskiej, Republiki Estońskiej, Republiki Cypryjskiej, Republiki Łotewskiej, Republiki Litewskiej, Republiki Węierskiej, Republiki Malty, Rzeczypospolitej Polskiej, Republiki Stowenii i Republiki Stowackiej do Unii Europejskiej, podpisany w Atenach w dniu 16 kwietnia 2003 r. (2003), Dz. U. 2004, Nr 90, poz. 864/2.

Traktat o Unii Europejskiej (1992), Dz. Urz. UE C 191, 29.07.1992.

Traktat z Amsterdamu zmieniajacy Traktat o Unii Europejskiej, Traktaty ustanawiajace Wspólnoty Europejskie oraz niektóre zwiazane z nimi akty (1997), Dz. Urz. UE. C 340, 10.11.1997.

Uktad Europejski ustanawiający stowarzyszenie między Rzeczpospolita Polska z jednej strony, a Wspólnotami Europejskimi i ich państwami, z drugiej strony, sporządzony w Brukseli dnia 16 grudnia 1991 roku (1991), Dz. U. 1994, Nr 11, poz. 38.

Weatherill S. (2005), EU Consumer Law, Cheltenham, Northampton.

Wiewiórowska-Domagalska A. (2000), Europejskie prawo konsumenckie - rozwój, problemy, pytanie o przyszłość, in: Europejskie prawo konsumenckie a prawo polskie, eds. E. Nowińska, P. Cebula, Zakamycze.

Włodarska-Dziurzyńska K. (2009), Sankcje w prawie konsumenckim na przykładzie wybranych umów, Warszawa.

Żuławska C. (1994-1995), O prawach konsumenta w okresie przemian, „Roczniki Nauk Społecznych. Nauki Społeczno-Ekonomiczne," z. 1.

\section{Summary}

The article is based on an analysis of national and international legislation, on documentation and on the subject literature. It aims to present the adaptation process of Polish consumer 
policy to European standards. The article discusses the legal basis for the adjustment of national consumer legislation and the strategies of consumer policies towards the European Union. The second part of the article describes the process of adjustment of Polish legislation to the EU legislation. The last part includes concluding remarks and elaborations concerning the actual problems of the Union connected with the implementation of consumer-protection-related regulations into the national legal standards, the function and the role of relevant consumer policy.

Key words: integration, consumer policy, consumer rights, European Union

\section{Polityka konsumencka w procesie akcesji Rzeczypospolitej Polskiej do Unii Europejskiej}

\section{Streszczenie}

Artykuł oparty jest na analizie międzynarodowych oraz krajowych aktów prawnych, dokumentów oraz literatury przedmiotu. Ma on na celu przedstawienie procesu dostosowania polskiej polityki konsumenckiej do standardów unijnych. W artykule omówione zostały podstawy prawne harmonizacji konsumenckich praw krajowych z prawem UE, jak również tożsamość krajowych strategii polityki konsumenckiej do unijnych. W kolejnej części artykułu analizie poddano proces dostosowania polskiego prawodawstwa do unijnego. Ostatnia część opracowania pełni rolę konkluzji, zawiera rozważania na temat faktycznych problemów Unii Europejskiej związanych z obowiązkiem implementacji regulacji dotyczących ochrony konsumenta do narodowych standardów prawnych oraz faktycznej funkcji i zasadności prowadzenia przez państwo odpowiedniej polityki konsumenckiej.

Słowa kluczowe: integracja, polityka konsumencka, prawa konsumentów, Unia Europejska 
